Original Article

\title{
Medical, psychoanalytical, and political thoughts on a shared obsessional neurosis
}

\section{Yorgos Dimitriadis}

Department of psychoanalytic studies, CRPMS Laboratory (FR-75013), Université de Paris, 5, place Paul Ricoeur, 75013 Paris, France.

E-mail: dimitriadisyorgos@gmail.com

\begin{abstract}
The scope of this paper is to present some medical, psychoanalytic, and political thoughts on the Covid-19 pandemic. A medical catastrophe cannot be without political consequences and indeed, in this initial period of the pandemic, the stakes are already high, with increased risks of nationalism, totalitarianism, digital capitalism, and medical populism. The Lacanian categories of the Real and the Symbolic, the clinical structure of obsessional neurosis, and the concepts of enjoyment and of the "letter" are the tools used in the paper. On this basis, Lacanian psychoanalysis, in dialogue with medicine, political science, and sociology, presents an analysis of the pandemic crisis. Psychoanalysis, Culture \& Society (2021) 26, 548-560. https://doi.org/10.1057/ s41282-021-00233-5; published online 24 September 2021
\end{abstract}

Keywords: Covid-19; medicine; Lacan psychoanalysis; political sciences; sociology

\section{Introduction}

Jacques Lacan (1975) claimed that what we call History is in fact the history of epidemics. Lacan uses the term "epidemic" broadly, considering even "the plague of psychoanalysis" ${ }^{1}$ - like the Roman Empire and Christianity in their time - to be an epidemic. The Covid-19 pandemic reminds us that we are prone to catastrophes but do not have the ability to integrate them in any significant sense (Hoffmann, 2015) - at least during the period of

Translator: Clémence Sebag. The paper's translation fees were paid by the CRPMS. 
uncertainty that follows. The anxious expectation produced by this uncertainty impels us to seek meaning.

Collective uncertainty often leads to a call for totalitarianism by a sovereign authority. A populist government can play that part, especially a government led by a popular and totalitarian leader - as long as he or she has the charisma to align him/herself with the psychology of the crowd. Other types of digital, nationalist, "segregationist," or even medical totalitarianisms are also wont to emerge, in the guise of "solutions" to the uncertainty created by a catastrophe such as the Covid-19 pandemic.

Catastrophes can be natural, social, or economic, but they are usually found at the intersection of these areas. Echoing an observation made by Rudolph Virchow, the politician and father of pathological histology, ${ }^{2}$ as early as the 19th century, war, famine, and plague (which provoked until then the worst pandemics) are prone to come at the same time or one after the other (Lanteigne, 2000). In the words of Virchow, an epidemic is a social phenomenon with medical aspects (Ansermet, 2020). For instance, during the actual pandemic, we see this kind of intersection in relation to immigrants. According to the epidemiologist Marie Melchior (2021), "[a]lready severely impacted by the epidemic, the immigrant population's situation got worse in terms of employment or administrative processes, which is not without consequences for their health." We can also observe this intersection regarding the sword of Damocles of an economic crisis hanging over the world during the Covid pandemic.

\section{Beyond medical considerations: politics}

Between 1347 and 1352, the plague killed approximately one third of the European population (Institut Pasteur, 2007), while between 1918 and 1919 the Spanish flu killed $3.33 \%$ of the world population (CDC, 2020), albeit the value placed on human life at these times, as we will see later on, was not necessarily the same then as now. The relatively homogeneous response of societies to the Covid-19 epidemic is consistent with the enhancement of health as a result of technological advances, with health becoming a benefit to which we increasingly consider ourselves entitled. As Lacan (1966) said as early as 1966, "to the extent that medicine's relationship to health changes, that the kind of generalized power wielded by science gives everyone the opportunity to come and ask the doctor for his or her benefit ticket for a specific and immediate purpose, we can see the emergence of a new dimension which I will call 'the demand." However, our global relationship to health is now moving towards a "preactive" medicine that would, in the words of Barbara Stiegler (2020), make us sufficiently efficient to adapt to a degraded environment. Avoiding death thanks to the effectiveness of medicine's current prevention and reaction 
strategy has become an imperative of the highest priority. However, this was certainly not the case even as recently as the last century, with the Asian flu pandemic in 1957-8 and the 1968-9 flu in China (Marie et al., 2020).

It was with SARS-CoV-1 in 2003-4 and the swine flu pandemic in 2009-10 that states began to raise the alarm about the risk of epidemics (Marie et al., 2020). However, the Covid-19 pandemic is the first time that public health has been prioritized over the economy in most developed countries ${ }^{3}$ as governments decided to control population movement with lockdowns. This was a political decision of utmost urgency, irrespective of the epidemiological considerations of the long-term impact of lockdown on herd immunity. As the death toll continued to rise, the governments of most developed countries could not afford to be seen as passive, while in some countries, as time passed, it became impossible to continue to support a policy of fiscal restraint in matters pertaining to public health. The proximity of this Real of death needed to be kept at bay, as it would have traumatized the vast majority of citizens, for whom its presence has become, in recent decades, something quite virtual belonging chiefly to autopsies on TV screens and/or to the horror genre - in which this virtualization of death exemplifies the "mastery of the uncanny."

\section{Segregation and totalitarianism}

However, the prioritization of health in most countries will have other political effects. The access to health will inevitably become selective, due to a lack of health resources in view of the unexpected scale of the pandemic. It will be a question of maximizing, as Jean-Pierre Dupuy (2020a) says in his dialogue with Alain Compte-Sponville, "not the number of lives saved, but the number of years of life saved." The Covid-19 pandemic also kills far more elderly people than younger people, while it is the latter who contribute most to its expansion (Kiem et al., 2021). This has led some, such as the French philosopher of ethics André Compte-Sponville (Dupuy, 2020a; Compte-Sponville, 2020), to consider that older people, given the choice, should "sacrifice" themselves for the younger generation, while the populist Brazilian president Jair Bolsonaro went as far as to say with the utmost cynical detachment: "We are sorry for the ravages the virus is causing among the elderly, but they have to die of something" (Dupuy, 2020b).

This view of the old as a population whose lives are considered by some to be worth less than those of the young (Dupuy, 2020a) is in line with the tendency towards "segregation" shown by Western societies, a tendency which Lacan (1968) had already denounced in 1968 as "the scar of the evaporation of the father" (Lacan, 1970, p. 84). It also goes hand in hand with the idealization of "youth" by our consumer societies, whose imperative is unlimited enjoyment ${ }^{4}$ (Melman, 2002). Segregation reduces the singularity of a subject to his or her 
specificity as an individual who shares traits with other individuals with whom he or she forms a group. This group is formed on an egalitarian basis of shared traits - particularly a claim to a certain type of enjoyment and everything associated with such enjoyment. The group is also placed in opposition to other groups that may limit this enjoyment. Here, what links the members of the group is no longer the common reference to a symbolic trait that aspires to universalism, but the community of enjoyment. This type of segregation can also be a form of totalitarianism when, for example, some groups, mostly of young people, under the pretext that they have nothing to fear, claim the freedom to enjoy life, without heeding the protective measures recommended by health and political authorities and while consequently risking spreading the virus to those who are more at risk. As David Le Breton (2020) puts it, "the claim to freedom, understood here as a detachment from the collective, pays little heed to the civility demanded by the health authorities [and] [...] even reflects a moral disengagement [...] The social bond is fragmented into a mosaic of individuals pursuing their own interests, careless of the whole."

But segregation can even go beyond the individual life expectancy criteria of each patient. A class effect is already present. According to an Inserm EpiCov survey (Presse Inserm, 2020), the results of which were released on October 9, 2020 , during the first wave of the pandemic there was a cumulative rise in social inequalities. Thus, the report concluded that these social groups were most at risk of exposure to the virus and, while adopting the protective measures just as readily as any other group, those that were most often infected. The survey also found that the social groups most at risk were those with the most associated pathologies. Lastly, these groups experienced a marked deterioration of their financial situation during lockdown, being mostly composed of poor, urban, poorly housed, immigrant subgroups of the population. Moreover, in poor countries or in countries with significant socio-economic inequalities, the poorest will of course tend to receive the least effective treatment. The consequences of the pandemic for economies, despite the courageous and drastic countermeasures taken by several states, have only just begun, whose socioeconomic impact leads to a generalized health crisis that first affects the most underprivileged classes. We have been warned.

\section{Digital surveillance capitalism}

The state of emergency declared in a number of states in response to the pandemic has already led to certain abuses (Agamben, 2020), which have gone as far as mandatory surveillance of travel via smartphones in countries such as China. There is a danger that the state of emergency will become a totalitarian ideal, even for democratic states, as well as the consequential danger of the abuse of the possibilities offered by big data. Public health could thus become a 
pretext for encroaching on political life, through, for example, a so-called nationalism capable of confining epidemics, or another form of totalitarianism improvised on the spot - namely, digital capitalism - through changes in consumer behaviour and further proletarianization, as we shall see below. Big data accelerated the arrival of the current health crisis and, moreover, contributed to the shortage of the means that would have been necessary to contain it. Contagion is facilitated by the mimetic effects of consumption to the detriment of diversity, while consumption is widely promoted by current marketing means through the GAFA. In the age of the "data economy" (Bernard Stiegler, 2020), a risk that cannot be calculated by data manipulation is an invisible risk - common sense notwithstanding. The need for a stock of masks, though there are no immediate plans to use them, is one such example. As Bernard Stiegler (2020) says,

the current economy is based on information that stands in for knowledge and is itself completely calculable - turning us into calculated, mimetic and remote-controlled beings [...] This model [...] is very dangerous because it eliminates diversity, which is the prerequisite for resilience. By trying to optimize everything through algorithms, we decrease resilience while living in a tight-flow situation - the effects of which we see in the various shortages [...] The current system is based entirely on automated ratios that tend to eliminate what is incalculable. Faced with these incalculables, systems go into crisis [...] We have forgotten that risks are never in the calculation of averages.

Nevertheless, Stiegler (2015) specifies that he is not hostile to automation quite the opposite - but on the condition that "it must be used to interpret, diversify and compare points of view" (p. 340).

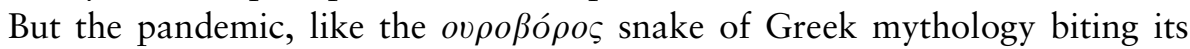
own tail, is pushing for an ever more pervasive digitalization. During the lockdown, almost half of employees in Europe (Eurofound, 2020) were transformed into teleworkers in just a few days. There is the risk that, given the savings that this implies in office overheads, after the crisis employers will continue to encourage remote work, although this is a controversial issue (Bérastégui, 2021; Sunak, 2021). Proletarianization, Stiegler (2013) states, "consists in depriving a subject (producer, consumer, designer) of his knowledge (know-how, savoir-vivre, design and theorizing know-how)" (p. 424). Assembly-line production in the industrial era caused mass proletarianization, while in the post-industrial era remote work results in a digitized product that tends to erase the worker's personal singularity as well as the contingency of spontaneous interactions. The proletarian, claims Gilbert Simondon, "is de-individualized by the machine that has grammaticized and automated his knowledge" (Simondon, cited in Stiegler, 2013, p. 424). The rules of communication in 
remote work are becoming those of a computer, leading to homogenized interpretations and sanitized interactions in favour of a single understanding making the very possibility of their existence and timing dependent on that of the artificial intelligence.

Moreover, online commerce, which enjoyed very steep growth during lockdown, will certainly continue to flourish, given the addictive force of consumer behavior - thanks to marketing which has "proletarianized" the consumer by transforming his lifestyle into an instruction manual (p. 424). Local businesses have suffered, while methods have become increasingly dehumanized (virtual assistants, drives, soon drones, etc.). However, the service industry goes far beyond the sale of industrial products. As Daniel Cohen (2020) states, "there have always been services, but they came second to the industrial sector that drove them. This is no longer the case. There are few jobs in the industrial sector nowadays, and the bulk of our consumption, goods and jobs reside in the tertiary sector." Reducing the cost of these services through automatic procedures is becoming an obsession for post-industrial capitalism, and digital technology offers an outstanding opportunity to do so. As Cohen goes on to argue,

over the last ten years or so, we have seen that the digital society is offering a solution to this growth problem, but by basically doing the same thing as industrial society did in its time, that is, by dehumanizing social relations [...] Covid-19 is a health crisis which a priori as far as we can tell has very little to do with what is being said about it. In reality, this period is in the process of being lived out as an acceleration of the transformations of the digital society. By making society phobic about face-to-face relationships, the health crisis is accelerating precisely what the digital society is built and designed to do: absolving people from face-to-face and in-person interactions. (Cohen, 2020)

\section{Epidemics of a shared obsessional neurosis}

On a more individual level, the fear of contagion could provide an additional pretext to lock individualism (or communitarianism) into a generalized "madness of doubt with delirium of touch" (Legrand du Saulle, 1875). As Charles Melman (2015) states, "one paradox that is well known is that people generally do much better during crises [...] since the crisis somehow brings together the inner malaise and the public malaise, in such a way that they are finally shared. Neurotic disorders are paradoxically relieved in times of war" (p. 29). AIDS had long-term consequences for our social manners and Covid may have too, since in both cases we applied social distancing for safety reasons. AIDS also contributed to neo-moralism and a certain sexual asepticism of social 
spaces. Isolating ourselves at home while possibly keeping in touch via the Internet has been the most common way to socialize during the peaks of the pandemic. Couldn't Covid be a new occasion for people to create new social codes, with overprotective manners of getting in contact with each other? After the paranoia in times of war (Raihani and Bell, 2019), obsessive neurosis in times of pandemics gives the psychopathological example of a Darwinian advantage.

In a globalized world, "no one [.. .] is protected against the consequences of a lack of hygiene on a Chinese market" (Attali, 2020, p. 127). We are "contaminated" by the Other's desire from the day we are born, or even before that by the context that allowed us to come into the world. The obsessive fantasy of returning to the maternal womb free from desire finds its perfect fulfilment during lockdown: behind the screen of a computer, while working from home or through virtual sex, far from the contagious risk of the Other's desire and the enjoyment of our peers. In trying to move towards desire, an obsessive person destroys the Other's desire. ${ }^{5}$ Such a person tends to render inanimate, through fetishist mastery, the object of his or her desire, thereby rendering it impossible (Lacan, 1958-9/2019). This object is also relative, as Alain Vanier (2005) says, to the gadgets that enable him to communicate remotely, through which he can safely enjoy in a more or less masturbatory manner, thus fitting into our society's consumer and security concerns. But enjoyment is always enjoyment of the living organism ${ }^{6}$ and can catch up with obsessive people through their hypochondriacal and microbiophobic ruminations, by means of which they enjoy their thoughts at precisely those moments when their enjoyment loses its autarchy due to the effects of the excess of enjoyment of another body on their own - a body which can be as small as a virus, which in turn needs another organism to live and to enjoy.

\section{Ethics of psychoanalysis and the Lacanian concept of "the Real"7}

Deadly pandemics are an effect of the enjoyment of living organisms' enjoyment. This is simply Darwinian logic: a virus or a bacterium changes hosts, passing from an animal (zoonosis) or a plant organism to a human, adapting by mutations to the new host's detriment. No need for malice or for biological weapons: nature - despite medical exploits - stills reigns supreme. Indeed, waiting for good weather or collective immunity for the epidemic to stop is a way of a handing over to "Nature" the job of finding the pharmakon. Can we learn from the experience of Covid that our capacity to dominate "Nature," regardless of scientific progress, is quite limited and that "Nature" usually has the last word?

In addition, according to some researchers (Sham, 2020), human beings' harmful impact on nature (deforestation, urbanization, species extinction, 
industrial animal husbandry, consumption of wild animals stacked in markets etc.) increases the risk of contamination by zoonoses. The speed at which an infected person will travel around what he or she considers to be "his" or "her" planet is ever increasing. The consequences of this globalization are now proven (Sham, 2020), but will our long-term memory not yield to denial just as soon as the immediate effects of the pandemic have passed?

Natural disasters are occurring at an ever-increasing frequency, induced by human activity, stemming as they do from globalization and rampant neoliberalism. The nuclear threat, the greenhouse effect, and terrorism - all of which are already pervasive - are phenomena closely linked to human agency, at an individual and especially collective level. The ethics of psychoanalysis deal with the "Real" that determines, on the one hand, our specifically human selfdestructive inclinations and, on the other, the inability of "the Symbolic" to wipe out this same "Real." This is a structural inability, but it is amplified by pervasive techno-scientific progress, catching individuals and societies unprepared, and leaving them unable to absorb this progress for want of solid symbolic structures. Some call for a degrowth "of the economy of the frivolous, of the illusory of the disposable" (Morin, 2020), but this voice is faint in the face of the addictive power of consumption, coupled with the techno-scientific possibility of producing so-called "goods."

\section{The gap in knowledge and the necessity of anticipated certainty}

In a globalized world, the response to global disasters must be the concern of humanity as a whole. Even if the pandemic moves to another continent, its tide can mutate and return to its starting point, because SARS-CoV-2 knows no borders between countries nor races. It may be abated by good weather, a drug, or more probably a vaccine, but the solution is contingent. Before the Covid-19 era, the French philosopher and engineer Jean-Pierre Dupuy (2018) had already said that we must not simply make catastrophes possible but deliberately write them into our future, always considering that the worst is a definite certainty. Working within the bounds of such anticipated certainties - as proposed by Dupuy (2015) - is an approach that is analogous to that of "the Real" of the letter, which latter Lacan (2001) compared to a "littoral," i.e. that which is "at the edge of the hole in knowledge" (p. 14).

It seems that the "Real" of our biology is sensitive to the language of the RNA of the coronavirus, whose enjoyment of the living vibrates with ours, and that of the equally vibrant "letter" conditioned by the unconscious belongs to the same heteronomy. As Lacan stated in a 10 May 1967 session, "The Other [...] is the body" (Lacan, 1966-7). In the words of Jean-Claude Milner (2011), it is perhaps not by chance that genetics - currently the dominant influence in science - and life sciences as a whole "insists on literalisation, on the analogy 
between genes and letter sequences” (p. 17). The semiotics of our DNA-literate body can thus find itself resonating with the letters of the unconscious, this semiotics which governs the contingency of its enjoyment, beyond any signifying determinism - which, for its part, tends to evacuate, i.e. to limit enjoyment.

\section{Casuistic, evidence-based medicine and "medicalized" populism}

Speaking of life sciences, the current pandemic also calls for biomedical research here and now - not unlike what analysts do when each case forces them to reinvent psychoanalysis. ${ }^{8}$ The careful observation of each medical case could lead to better care, in the sense of personalized, patient-oriented medicine, instead of standardized protocols - all the more so when there are no specific treatments of proven efficacity. Yet the interesting debate between medical casuistic and evidence-based medicine (Advenier, 2010) should not lead to "medicalized" populism.

Uncertainty does indeed call for a sovereign authority. This could be especially during a pandemic - a charismatic medical doctor/researcher whose popularity might turn him into a guru - or even, why not? - a political leader. Many discoveries in medicine - including several drugs from Largactil ${ }^{\circledR}$ to Viagra ${ }^{\circledR}$ - are the fortuitous result of simple observation, analogical reasoning, and trial and error, before there is any possible evidence through randomized studies, which often give discordant results (Ioannides, 2005). But this cannot be a pretext for statements made without necessary caution and checks, as when these are mediatized (Castel, 2020), they can push patients, and even physicians, to "therapeutic" acting-out, and researchers to carry out a plethora of useless trials. $^{9}$

Conflict of interest On behalf of all authors, the corresponding author states that there is no conflict of interest.

\section{About the Author}

Yorgos Dimitriadis is a psychiatrist, Lacanian psychoanalyst and member of the Association Lacanienne Internationale, working in Paris. He is Full Professor of Psychopathology in the Department of Psychoanalytic Studies, University of Paris. For his research orientation and previous publications, see http://www.ep. univ-paris-diderot.fr/recherche/crpms/membres-du-crpms/ec-08/. 


\section{Notes}

1 In 1909, on their way to Clark University, Freud critiqued Jung's enthusiasm about their arrival in the US, stating that by bringing psychoanalysis to America they were bringing the plague.

2 The great hygienist did not, however, believe that epidemics originated in bacteria nor did he believe in the theory of the evolution of species.

3 The social Darwinism of the Far West, as we can see, may be an exception, but other "unabashed" neoliberalism will probably follow.

4 I use the term "enjoyment" for the Lacanian term jouissance, even though this translation is not quite accurate. For an introduction to the latter concept, see Dimitriadis (2017).

5 Regarding the obsessional neurotic's desire, see Lacan's (1957-8/2017) seminar The Formations On the Unconscious and the sessions of 4 and 21 May, 11, 18, and 25 June, and 2 July 1958.

6 As Lacan says in his seminar Encore, the French word "encore," which means "again," can also be heard as "en-corps," meaning "in-body" (which we can in turn hear as "embody”). As Lacan (19723) asks, "Isn't that precisely what psychoanalytic experience presupposes?- the substance of the body, on the condition that it is defined only as that which enjoys itself" (p. 23).

7 For the Lacanian concepts of the Real and the Symbolic, see Stanford Encyclopedia of Philosophy (2020).

8 “The last flower of medicine," as Lacan (1975) said.

9 In an anti-Covid database of 8 May, there were 183 unregistered trials related to hydroxychloroquine (Foucart, 2020).

\section{References}

Advenier, F. (2010) Le raisonnement pratique: entre causistique et statistique. AMP 168(2): $152-5$.

Agamben, G. (2020) L'épidémie montre clairement que l'état d'exception est devenu la condition normale. Le Monde, 25 April. https://www.lemonde.fr/idees/article/2020/03/ 24/giorgio-agamben-l-epidemie-montre-clairement-que-l-etat-d-exception-est-devenula-condition-normale_6034245_3232.html, accessed 9 May 2020.

Ansermet, F. (2020) A chacun sa pandémie. Lacan Quotidien, 25 March. https:// lacanquotidien.fr/blog/wp-content/uploads/2020/03/LQ-876.pdf, accessed 9 May 2020.

Attali, J. (2020) L'économie de la vie. Paris: Fayard.

Bérastégui, P. (2021) Teleworking in the aftermath of the Covid-19 pandemic: enabling conditions for a successful transition. European Economic, Employment and Social Policy, 2021.05. https://www.etui.org/sites/default/files/2021-05/Teleworking\%20in\% 20the \%20aftermath $\% 20$ of $\% 20$ the $\% 20$ Covid-19\%20pandemic. $\% 20$ Enabling $\%$ 20conditions \%20for\%20a\%20successful\%20transition.pdf, accessed 21 August 2021.

Castel, P.-H. (2020) L'hydroxychloroquine: quelle(s) controverse(s)? Journal en ligne AOC, 12 April. https://aoc.media/opinion/2020/04/12/lhydroxychloroquine-quellescontroverses/, accessed 9 May 2020.

CDC (2020) 1918 Pandemic (H1N1 virus). https://www.cdc.gov/flu/pandemic-resources/ 1918-pandemic-h1n1.html, accessed 9 May 2020.

Cohen, D. (2020) La crise se paye elle-même par les taux bas. Le Monde, 23 October. https://www.lemonde.fr/economie/article/2020/10/23/daniel-cohen-la-crise-se-payeelle-meme-par-les-taux-bas_6057090_3234.html, accessed 9 May 2020. 
Compte-Sponville, A. (2020) Réponse d'André Compte-Sponville à Jean-Pierre Dupuy. Arte Filosofia, 25 May 2020. https://www.artefilosofia.com/reponse-dandre-comtesponville-a-jean-pierre-dupuy/, accessed 21 August 2021.

Dimitriadis, Y. (2017) The psychoanalytic concept of jouissance in psychoanalysis and the kindling hypothesis. Frontiers in Psychoanalysis and Neuropsychoanalysis 8: 1-12. https://doi.org/10.3389/fpsyg.2017.01593.

Dupuy, J.-P. (2015) A Short Treatise on the Metaphysics of Tsunamis. Lansing: Michigan State University Press.

Dupuy, J.-P. (2018) Jean-Pierre Dupuy ou l'imminence de la catastrophe. France Culture, 21 August. https://www.franceculture.fr/emissions/le-malheur-des-uns/jean-pierredupuy-ou-limminence-de-la-catastrophe, accessed 9 May 2020.

Dupuy, J.-P. (2020a) Le virus du sophisme, lettre à André Compte-Sponville. Journal en ligne AOC, 4 June. https://aoc.media/opinion/2020/06/03/le-virus-du-sophisme-lettre-aandre-comte-sponville/, accessed 9 May 2020.

Dupuy, J.-P. (2020b) Si nous sommes la seule cause des maux qui nous frappent, alors notre responsabilité devient démesurée. Le Monde, 3 July. https:/www.lemonde.fr/idees/ article/2020/07/03/jean-pierre-dupuy-si-nous-sommes-la-seule-cause-des-maux-quinous-frappent-alors-notre-responsabilite-devient-demesuree_6045012_3232.html, accessed 9 May 2020.

Eurofound (2020) Living, working and COVID-19. COVID-19 series. Luxembourg: Publication Office of the European Union. https:/www.eurofound.europa.eu/sites/ default/files/ef_publication/field_ef_document/ef20059en.pdf, accessed 9 May 2020.

Foucart, S. (2020) Le Covid, ou la fin de la confiance. Le Monde, 11 May, p. 34.

Hoffmann, C. (2015) Trauma and catastrophes today. Recherches en Psychanalyse 2(20): 98-9. https://www.cairn-int.info/journal-research-in-psychoanalysis2-2015-2-page-98. htm, accessed 9 May 2020.

Institut Pasteur (2007) Peste. https://www.pasteur.fr/fr/centre-medical/fiches-maladies/ peste,

Ioannides, J. (2005) Why most published research findings are false. PLOS Medicine 2(8). https://doi.org/10.1371/journal.pmed.0020124, accessed 9 May 2020.

Kiem, C., Bosetti, P., Paireau, J., Crepey, P., Salje, H., Lefrancq, N., Fontanet, A., Benamouzig, D., Boëlle, P.-Y., Desenclos, J.-C., Opatowski, L., and Cauchemez, S. SARS-CoV-2 transmission across age groups in France and implications for control.2021. pasteur-03170966. Prepublication. https://hal-pasteur.archives-ouvertes.fr/ pasteur-03170966/document, accessed 14 August 2020.

Lacan, J. (1957-8/2017) The Formations on the Unconscious, The Seminar of Jacques Lacan, Book V. Edited by J.-A. Miller. Translated by R. Grigg. Cambridge, UK: Polity Press.

Lacan, J. (1958-9/2019) Desire and its Interpretation, The Seminar of Jacques Lacan, Book VI. Edited by J.-A. Miller. Translated by B. Fink. Cambridge, UK: Polity Press.

Lacan, J. (1966) Table ronde, Psychanalyse et médecine. Cahiers du Collège de médecine 7(12): 761-74. http://aejcpp.free.fr/lacan/1966-02-16.htm, accessed 9 May 2020.

Lacan, J. (1968) Seconde version de la proposition du 9 octobre 1967 sur le psychanalyste de l'école. Scilicet 1: 14-30.

Lacan, J. (1970) Comment on M. De Certeau's intervention: Ce que Freud fait de l'histoire. Lettres de l'École freudienne 7(2): 84. https://ecole-lacanienne.net/wp-content/uploads/ 2016/04/Lettres-EFP-N7-Mars-1970-part2.pdf, accessed 9 May 2020. 
Lacan, J. (1966-7) The Logic of Phantasy, The Seminar of Jacques Lacan, Book XIV, unpublished. Translated by C. Gallagher from unedited French manuscripts. http:// www.lacaninireland.com/web/wp-content/uploads/2010/06/THE-SEMINAR-OF-

JACQUES-LACAN-XIV.pdf, accessed 20 August 2021.

Lacan, J. (1972-3) Encore, The Limits of Love and Knowledge, The Seminar of Jacques Lacan, Book XX. Edited by J.-A. Miller. Translated by B. Fink. New York: Norton.

Lacan, J. (1975) Yale University, Kanzer seminar. Silicet 6(7): 7-31. https://freud2lacan.bcdn.net/YaleNov24-bilingual.pdf, accessed 1 September 2021.

Lacan, J. (2001) Lituraterre. In: Autres Écrits. Paris: Seuil, pp. 11-20.

Lanteigne, J. (2000) La figure exemplaire de Rudolf Virchow. L’Agora 8(3). http://agora. qc.ca/Documents/Rudolf_Virchow-La_figure_exemplaire_de_Rudolf_Virchow_par_ Josette_Lanteigne, accessed 9 May 2020.

Le Breton, D. (2020) Coronavirus: «"Ensemble” est devenu un terme de circonstance». Le Monde, 6 August. https://www.lemonde.fr/idees/article/2020/08/06/coronavirusensemble-est-devenu-un-terme-de-circonstance_6048261_3232.html, accessed 9 May 2020 .

Legrand du Saulle, H. (1875) La folie du doute avec délire du toucher. https://archive.org/ stream/BIUSante_155857/BIUSante_155857_djvu.txt.

Marie, P., Masson, M., and Sarfati, Y. (2020) Psychanalyse au temps du coronavirus, Le blog de Pierre Marie, 14-15 November. https://blogs.mediapart.fr/pierre-marie/blog/ 010420/psychanalyse-au-temps-du-coronavirus, accessed 9 May 2020.

Melchior, M. (2021) Immigration: «La crise liée au Covid-19 précipite des milliers de personnes dans un abîme de non-droit». Le Monde, 18 January. https://www.lemonde. fr/idees/article/2021/01/18/immigration-la-crise-liee-au-covid-19-precipite-des-milliersde-personnes-dans-un-abime-de-non-droit_6066619_3232.html, accessed 9 May 2020.

Melman, C. (2002) L’homme sans gravité. Paris: Denoël.

Melman, C. (2015) La prévalence du réel social sur le réel psychique. Revue Passages 184: 29-31. https://www.freud-lacan.com/getpagedocument/28373, accessed 9 May 2020.

Milner, J.-C. (2011) Clartés de tout. Paris: Verdier.

Morin, E. (2020) Cette crise nous pousse à nous interroger sur notre mode de vie, sur nos vrais besoins masqués dans les aliénations du quotidien. Le Monde, 19-20 April. https:// www.lemonde.fr/idees/article/2020/04/19/edgar-morin-la-crise-due-au-coronavirusdevrait-ouvrir-nos-esprits-depuis-longtemps-confines-sur-1-immediat_6037066_3232. html, accessed 9 May 2020.

Presse Inserm (2020) Premiers résultats des enquêtes de santé publique de l'Inserm sur la Covid-19: facteurs de risques individuels et sociaux, 9 October. https://presse.inserm.fr/ premiers-resultats-des-enquetes-de-sante-publique-de-linserm-sur-la-covid-19-facteursde-risque-individuels-et-sociaux/41032/, accessed 9 May 2020.

Raihani, N. and Bell, V. (2019) An evolutionary perspective on paranoia. Nature Human Behaviour 3(2): 114-21. https://doi.org/10.1038/s41562-018-0495-0.

Sham, S. (2020) Contre les pandémies, l'écologie. Le Monde diplomatique, March, pp. 1, 21. https://www.monde-diplomatique.fr/2020/03/SHAH/61547, accessed 9 May 2020.

Stanford Encyclopedia of Philosophy (2020) Jacques Lacan. https://plato.stanford.edu/ entries/lacan/, accessed 9 May 2020.

Stiegler, B. (2015) Dialogue avec Bernard Stiegler. In: M. Wolf Proust et le calamar. Angoulème: Abeille et castor, pp. 321-45. 
Stiegler, Barbara. (2020) La crise due au coronavirus reflète la vision néolibérale de la santé publique. Le Monde, 10 April. https://www.lemonde.fr/idees/article/2020/04/09/ barbara-stiegler-la-crise-due-au-coronavirus-reflete-la-vision-neoliberale-de-la-santepublique_6036059_3232.html, accessed 9 May 2020.

Stiegler, Bernard. (2020) Interview du philosophe Bernard Stiegler sur la crise du COVID-19. Observatoire BV2 des mémoires. 30th April. https://www.observatoireb2vdesmemoires. $\mathrm{fr} /$ publications/interview-du-philosophe-bernard-stiegler-sur-la-crise-du-covid-19, accessed 9 May 2020.

Stiegler, B. and Petit, V. (2013) Pharmacologie du Front national suivi du Vocabulaire d'Ars Industrialis. Paris: Flammarion.

Sunak, R. (2021) Rishi Sunak warns young home working may hurt their career. BBC News, 3 August. https://www.bbc.com/news/business-58068998, accessed 21 August 2021.

Vanier, A. (2005) Névrose obsessionnelle, névrose idéale. Figures De La Psychanalyse 2(12): 85-92.

Publisher's Note Springer Nature remains neutral with regard to jurisdictional claims in published maps and institutional affiliations. 